\title{
PW02-020 - Colitis revealing mevalonate kinase deficiency
}

\author{
L Michael $^{1^{*}}$, J Camille ${ }^{2}$, BM Brigitte ${ }^{3}$ \\ From 7th Congress of International Society of Systemic Auto-Inflammatory Diseases (ISSAID) \\ Lausanne, Switerland. 22-26 May 2013
}

\section{Introduction}

Hyperimmunoglobulinemia D (HIDS) is the less severe form of mevalonate kinase deficiency (MKD) caused by recessive inherited mutation in the mevalonate kinase gene $(M V K)$. HIDS is characterized by febrile attacks, often associated with transient digestive manifestations, such as abdominal pain, diarrhea and vomiting.

\section{Case report}

Here we report for the first time two patients with MKD revealed by a severe neonatal colitis. Both patients had chronic bloody diarrhea and failure to thrive, one patient since the age of one month and the other twelve days. Total parenteral nutrition was required. A marked elevation of acute phase reactants was present, and no evidence of infection was found. In patient 1, ileocolonoscopy revealed an ulcerative colitis at the age of 5 months. Patient 2 suffered from enterocolitis and shock, associated with multiple bowel adhesions at age 5 weeks; the rectosigmoidoscopy showed aphtoid lesions of the sigmoid colon. Pathological findings of colonic biopsies revealed a dense polymorph inflammatory infiltrate associated with deep ulcerations. Febrile attacks occurred 2 months after the onset of digestive symptoms in patient 1 , and at onset of disease in patient 2. Genomic sequencing of the $M V K$ gene revealed compound heterozygous mutations in both patients. Anti-interleukin 1 (Anti-IL1) agent (anakinra) produced long-term remission of all digestive features and laboratory parameters.

\section{Discussion}

This report emphasizes that MKD may be the cause of severe early-onset inflammatory colitis, and must be considered by physicians, even in the absence of fever, after ruling out infections. Anti-IL1 therapy may result in a dramatic improvement of MKD-related inflammatory bowel disease.

\section{Disclosure of interest}

None declared.

\section{Authors' details}

${ }^{1}$ Hopital Robert Debré, Paris, France. ${ }^{2} \mathrm{CHI}$ Créteil, Créteil, France.

${ }^{3}$ Rhumatology, Hôpital Necker Enfants Malades, Paris, France.

Published: 8 November 2013

\section{References}

1. van der Hilst JC, Bodar EJ, Barron KS, Frenkel J, Drenth JP, van der Meer JW, et al: Long-term follow-up, clinical features, and quality of life in a series of 103 patients with hyperimmunoglobulinemia D syndrome. Medicine 2008, 87(6):301-310.

2. Bader-Meunier B, Florkin B, Sibilia J, Acquaviva C, Hachulla E, Grateau G, et al: Mevalonate kinase deficiency: a survey of 50 patients. Pediatrics 2011, 128(1):e152-159.

3. Touitou I, Lesage S, McDermott M, Cuisset L, Hoffman H, Dode C, et al: Infevers: an evolving mutation database for auto-inflammatory syndromes. Human mutation 2004, 24(3):194-198.

4. Cailliez M, Garaix F, Rousset-Rouviere C, Bruno D, Kone-Paut I, Sarles J, et al: Anakinra is safe and effective in controlling hyperimmunoglobulinaemia D syndrome-associated febrile crisis. Journal of inherited metabolic disease 2006, 29(6):763.

5. Nimubona L, Laloum D, Rolland MO, Read MH, Guillois B, Duhamel JF: An intestinal obstruction in an eight-month-old child suffering from mevalonic aciduria. Acta paediatrica 2002, 91(6):714-716.

6. Ruemmele FM, El Khoury MG, Talbotec C, Maurage C, Mougenot JF, Schmitz J, et al: Characteristics of inflammatory bowel disease with onset during the first year of life. Journal of pediatric gastroenterology and nutrition 2006, 43(5):603-609.

doi:10.1186/1546-0096-11-S1-A160

Cite this article as: Michael et al.: PW02-020 - Colitis revealing mevalonate kinase deficiency. Pediatric Rheumatology 2013 11(Suppl 1):A160. 